\title{
The Recombinant Vaccine against Human Chorionic Gonadotropin goes on Combined Immunogenicity, Safety and Efficacy Clinical Trials
}

\author{
Talwar GP*1, Radhey S Sarma², Jagdish C Gupta ${ }^{1}$, Kripa N Nand ${ }^{1}$, Bandivdekar AH ${ }^{3}$, Rohini Sehgal ${ }^{4}$, Indrani \\ Ganguli ${ }^{4}$ and Alka Kriplani ${ }^{4}$
}

${ }^{1}$ Talwar Research Foundation, India

${ }^{2}$ Indian Council of Medical Research, India

${ }^{3}$ National Institute for Research in Reproductive Health, India

${ }^{4}$ All India Institute of Medical Sciences, India

Submission: May 15, 2018; Published: July 05, 2018

*Corresponding author: GP Talwar, Talwar Research Foundation, New Delhi, India; Email: gptalwar@gmail.com

Abstract

A chemically synthesized vaccine inducing antibodies against human chorionic gonadotropin (hCG) was previously developed by Talwar et al. [1] which had undergone successfully Phase I and Phase II efficacy Clinical trials in sexually active women showing its ability to prevent pregnancy without derangement of ovulation,hormonal profiles and menstrual regularity (Table 1). It had high efficacy with only one pregnancy occurring in 1224 cycles. It was fully reversible and women desirous of having another child conceived readily on antibodies falling below 20ng/ $\mathrm{ml}$ binding capacity [2]. The progeny born to previously immunized women had developmental land marks and cognitive abilities similar to their siblings [3].

Keywords: Vaccine; Antibodies; Sexually active women; Pregnancy; Ovulation; Hormonal profiles; Menstrual regularity; High efficacy; Cognitive abilities; Genetically engineered; Recombinant vaccine; Mycobacterium indicus; Antibody titers; Genetic strains; Non-immunized marmosets; Toxicity; Mammalian Chromosome; Gross pathology; Immunogenicity; Progesterone; Fertility

Abbreviations MIP: Mycobacterium Indicus Pranii; RCGM: Review Committee on Genetic Manipulation; DCGI: Drugs Controller General of India; hCG: Human Chorionic Gonadotropin

\section{Clinical Image}

\section{Making of a recombinant vaccine}

The above mentioned vaccine in the form made in the laboratory was expensive and time consuming. In order to render it amenable to industrial production, we made a genetically engineered version of the vaccine, in which beta subunit of hCG was linked to B subunit of heat labile enterotoxin of E. coli as carrier [4]. Figure 1 shows the sequence of nucleotides of this recombinant vaccine.The recombinant vaccine adsorbed on alhydrogel with adjuvant autoclaved Mycobacterium indicus pranii (MIP), induced fairly high anti-hCG antibodies in not only BalbC, but also in other genetic strains of mice [5,6]. MIP is a potent invigorator of immune response [7]. Figure 2 shows the antibody titersand their duration in BalbC mice. It may be recalled that at $50 \mathrm{ng} / \mathrm{ml}$ antibody titers and above, women are protected to become pregnant. This recombinant vaccine was therefore highly immunogenic at least in mice.

\section{Priming with DNA vaccine}

Genetically engineered vaccines are made as both DNA and protein. What was amazing was the observation that if primary immunization is done with the DNA form of the vaccine, followed by injections of the Protein form of the vaccine, the antibody response is substantially higher (Figure 3). Thus to obtain optimal antibody response, the schedule of immunization will be to immunize with 2 primary injections of DNA form of the recombinant vaccine to begin with, followed by third and subsequent injections with the protein form of the recombinant vaccine.

\section{Safety and efficacy}

The safety and efficacy of the recombinant hCG $\beta$-LTB vaccine was evaluated in subhuman primate species, the marmosets, at the National Institute of Research in Reproductive Health, 


\section{Global Journal of Reproductive Medicine}

Mumbai. The vaccine was found fully safe. 8/9 immunized marmosets were protected from becoming pregnant on co- habitation with fertile males, whereas all non-immunized marmosets in the control group became pregnant.

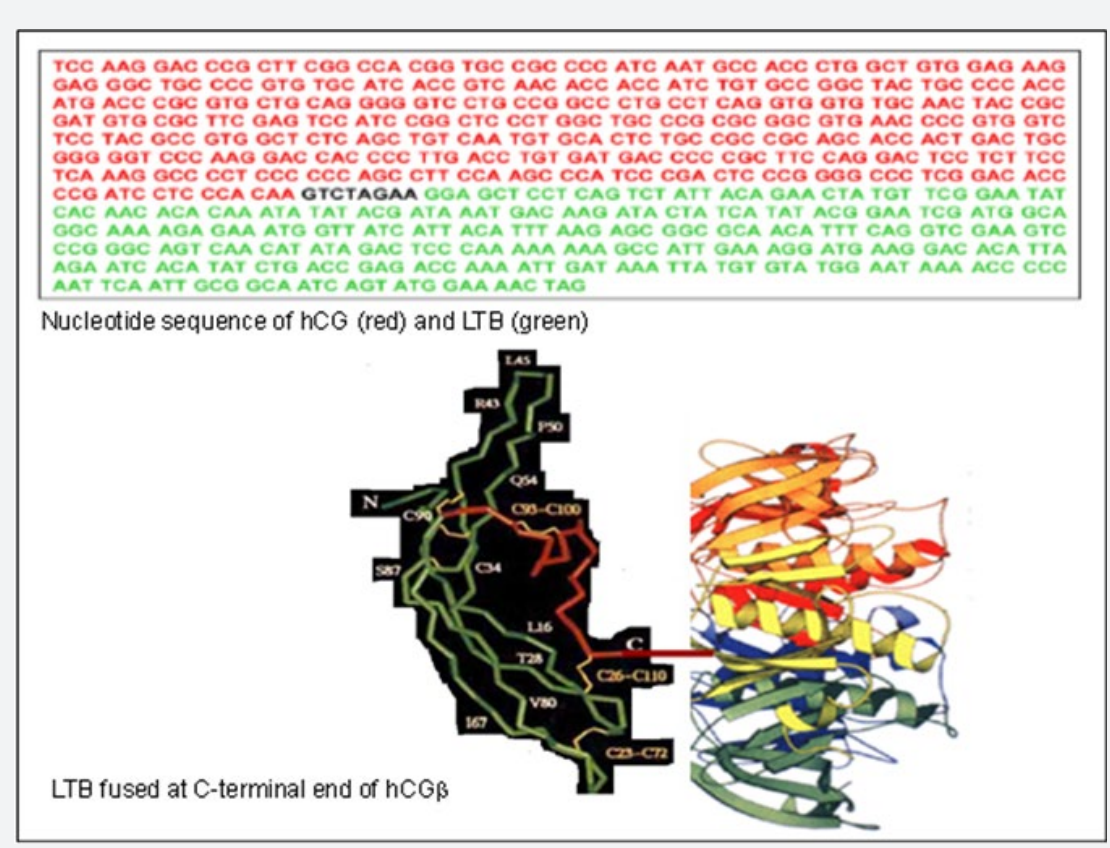

Figure 1: Conceptualized structure of $h C G \beta$-LTB vaccine. The carrier B chain of heat labile enterotoxin of $E$. coli (LTB) is fused at C-terminal glutamine of hCG $\beta$.

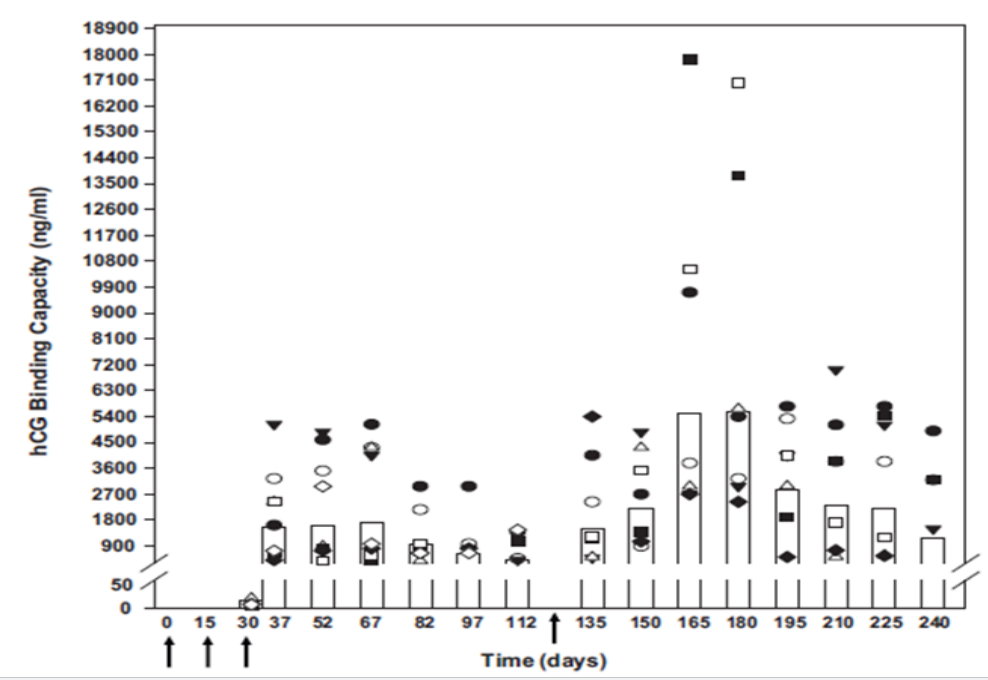

Figure 2: Antibody titers in Balb/C mice immunized with hCG $\beta$-LTB. Titers in each mouse are represented by different symbols. Bars represent the geometric means at various times following immunization.

\section{Toxicology}

Being a recombinant vaccine, its approval had to be obtained from Review Committee on Genetic Manipulation (RCGM), the National Committee for recombinant products. They demanded extensive toxicology on this vaccine from an independent GLP company. This was duly done by M/s Bioneeds at their GLP Facility in Bangalore, India. Both DNA and protein forms of the vaccine were non-sensitizing to the skin of guinea pigs with no clinical signs of toxicity, mortality and changes in body weight. Both vaccines were non-mutagenic at the highest concentration tested by Bacterial Reverse Mutation and Mammalian Chromosome Aberration Tests. Similar observation on non-mutagenic property of the vaccines was made in vivo by Mammalian Erythrocyte Micronucleus Test in Mice.Single dose acute toxicity study was conducted in Sprague Dawley rats. Vaccinated rats were observed for mortality, clinical signs of toxicity, body weight and gross pathological examination. No mortality, clinical signs of toxicity and treatment related changes in the body weight, were 


\section{Global Journal of Reproductive Medicine}

observed. No changes in gross pathology (external and internal) were observed at even the highest dose tested. Repeat doses of the vaccine were also tested in rats, which were followed up to 90 days post immunization. These studies showed no treatment related changes in physical, physiological, clinical, hematological parameters, as also in histopathology profiles of the organs.

Table 1: Efficacy of HSD-TT/DT vaccine to prevent Pregnancy.
Segment II studies in rats showed that vaccines did not affect the embryo-foetal development. Body weight, food consumption, gross pathology remained normal, and no abnormal effect was observed in fetal sex ratio, fetal weight, external, visceral and skeletal norms of fetuses [8] (Table 1).

\begin{tabular}{|c|c|c|c|c|}
\hline Women observed & Cycles Exposed above 50ng titers & Pregnancy & Luteal Progesterone & Menstrual cycles \\
\hline 110 & 1224 & 1 & $14-44 \mathrm{nM}$ & Regular \\
\hline
\end{tabular}

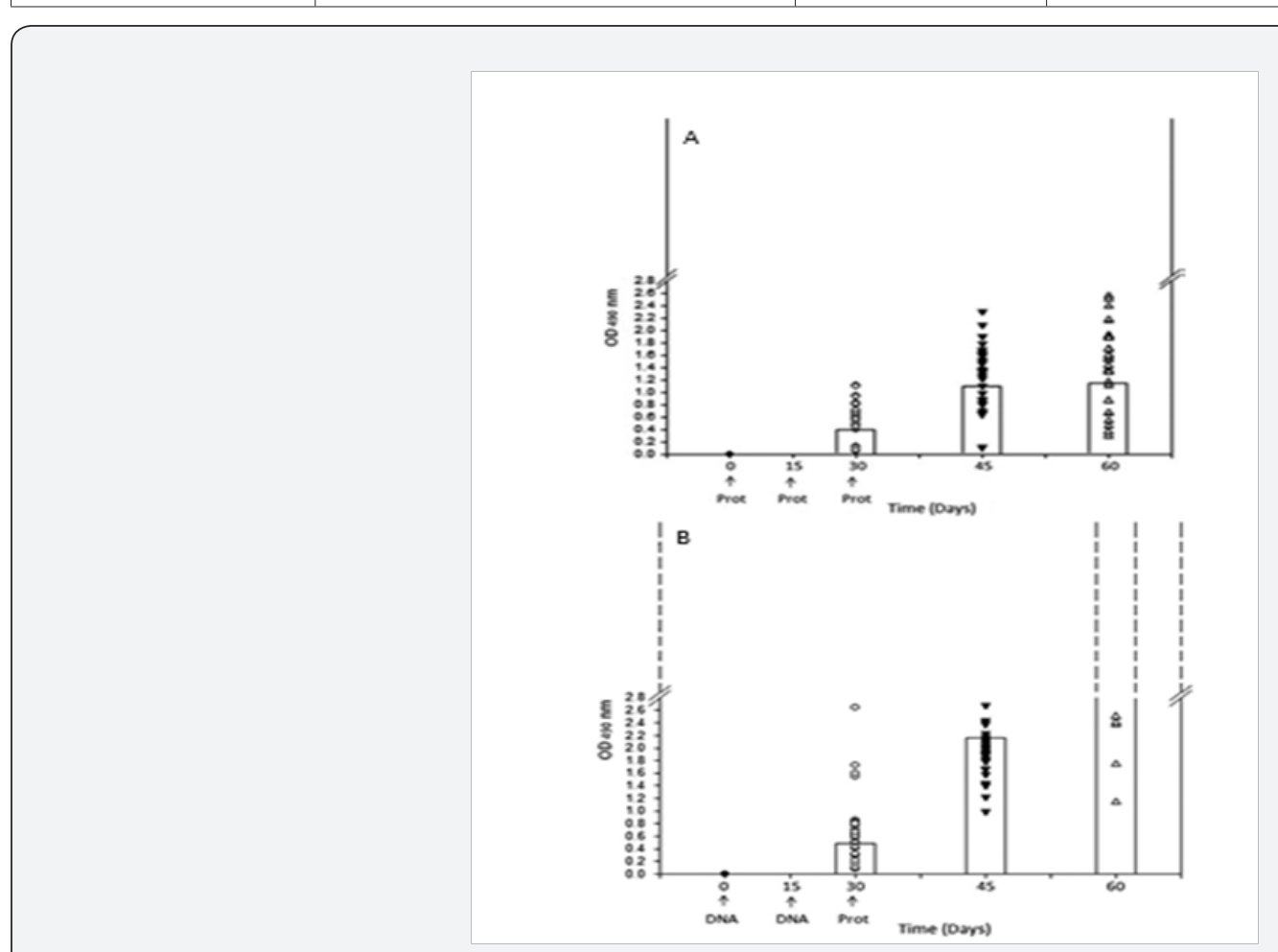

Figure 3: Effect of DNA priming on antibody titers in Balb/C mice.

(A) Anti hCG antibodies after 3 injections of proteinic form of the vaccine administered intra-muscularly.

(B) Anti hCG antibodies titers in mice primed twice with DNA form of the recombinant hCG $\beta$-LTB vaccine followed by the 3rd injection with proteinic form of the vaccine.

Symbols represent the individual values, while bars give the geometric mean at various time points post immunization. On day 60 , the antibody titers in 35 out of 40 mice were higher than the scale.

\section{Approval by RCGM and DCGI}

After obtaining the approval of RCGM, we applied for the approval of the Drugs Controller General of India for conducting clinical trials on a protocol which proposed immunogenicity studies at 100, 200, 300, 400 and $500 \mu \mathrm{g}$ dose of the protein form of the vaccine after priming with 2 doses of $1.5 \mathrm{mg}$ of the DNA vaccine. The study will be carried out in 50 women of reproductive age and proven fertility, 10 women at $100 \mu \mathrm{g}, 10$ at $200 \mu \mathrm{g}, 10$ at $300 \mu \mathrm{g}, 10$ at $400 \mu \mathrm{g}$ and 10 at $500 \mu \mathrm{g}$ dose of the protein vaccine. A range of parameters will be analyzed before and after immunization. All important laboratory investigations such as anti-hCGtiters, haematological parameters, lipid profile, liver function tests, kidney function tests, serum calcium and phosphorus, total protein, albumin, globulin, progesterone, TSH, prolactin, estrogen, auto antibodies, etc. will be carried out. The trials will be carried out at the reputed institutes, the All India Institute of Medical Sciences, New Delhi and Sir Gangaram Hospital, New Delhi. Subjects will also be clinically examined for weight, blood pressure, androgenism, pelvic TVS ultrasound, pyrexia, H/O joint pains, local reaction at the site of injection, persistent pain at the site of injection and swelling, if any. On completion of these studies satisfactorily, 70 women of proven fertility will be enrolled for efficacy studies. They would be immunized with 2 doses of $1.5 \mathrm{mg}$ of DNA form of the recombinant vaccine at 15 days interval followed by 2 injections of the protein form of the vaccine at the optimal dose determined in earlier phase of the trial. The IUDs will be removed and sexually active women will be observed for a period up to one year for remaining protected against pregnancy during the period, when antibody titers are above 50ng/ml hCG binding capacity. 


\section{Acknowledgement}

The Project is supported by a grant of the Indian Council of Medical Research.

\section{References}

1. Talwar GP, Singh O, Rao LV (1988) An improved immunogen for antihuman chorionic gonadotropin vaccine elicited antibodies reactive with a conformation native to the hormone without cross-reaction with human follicle stimulating hormone and human thyroid stimulating hormone. J Reprod Immunol 14(3): 203-212.

2. Talwar GP, Singh O, Pal R, Chatterjee N, Sahai P, et al. (1994) A vaccine that prevents pregnancy in women. Proc Natl Acad Sci USA 91(18): 8532-8536.

3. Singh M, Das SK, Suri S, Singh O, Talwar GP (1998) Regain of fertility and normality of progeny born at below protective threshold antibody titres in women immunized with HSD-TT vaccine. Am J Reprod Immunol 39(6): 395-398.

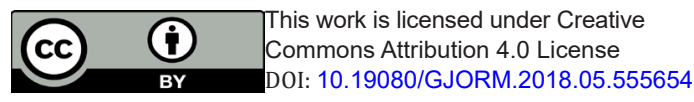

4. Talwar GP (2013) A Unique Vaccine for Control of Fertility and Therapy of Advanced Stage Terminal Cancers expressing ectopically hCG. Ann NY Acad Sci 1283: 50-56.

5. Purswani S, Talwar GP (2011) Development of a highly immunogenic recombinant candidate vaccine against human chorionic gonadotropin. Vaccine 29(12): 2341-2348.

6. Purswani S, Talwar GP, Vohra R, Pal R, Panda AK, et al. (2011) Mycobacterium indicus pranii is a potent immunomodulator for a recombinant vaccine against human chorionic gonadotropin. J Reprod Immunol 91(1-2): 24-30.

7. Talwar GP, Gupta JC, Mustafa AS, Kar HK, Katoch K, et al. (2017) Development of a potent invigorator of immune responses endowed with both preventive and therapeutic properties. Biologics 11: 55-63.

8. Nand KN, Gupta JC, Panda AK, Jain SK, Talwar GP (2015) Priming with DNA enhances considerably the immunogenicity of hCG $\beta$ - LTB vaccine. Am J Reprod Immunol 74(4): 302- 308.

Your next submission with Juniper Publishers
will reach you the below assets
- Quality Editorial service
- Swift Peer Review
- Reprints availability
- E-prints Service
- Manuscript Podcast for convenient understanding
- Global attainment for your research
- Manuscript accessibility in different formats
( Pdf, E-pub, Full Text, Audio)
- Unceasing customer service
Track the below URL for one-step submission
https://juniperpublishers.com/online-submission.php

